JPE (Jurnal Pendidikan Edutama) Vol. 5 No. 2 Juli 2018

P-ISSN : 2339-2258 (Print) E-ISSN: 2548-821X (Online)

http://ejurnal.ikippgribojonegoro.ac.id/index.php/JPE

\title{
EKSPERIMENTASI MODEL PEMBELAJARAN PEER-TUTORING TERHADAP PRESTASI BELAJAR MAHASISWA PROGRAM STUDI PENDIDIKAN MATEMATIKA
}

\author{
Dian Nurul Safitri \\ Fakultas Pendidikan Matematika dan Ilmu Pengetahuan Alam, IKIP PGRI Bojonegoro \\ email: dian.nurul88@gmail.com
}

\begin{abstract}
This current education requires that the learning process must be student centered. It is intended that the student can be participate in learning process, so that they can understand the material more. In college students are required to learn more independently. Students must have responsibility for themselves as well as their class. Learning by using Peer Tutoring helps students to be more independent and responsible for their learning. This study aims to prove the effectiveness of the peer tutoring model to the student's learning achievement. The subject of this research is the student of the Mathematics Education department. This research is a experimental research with quantitative approach. Data analysis used is statistical test with $t$ test. Before analyzing with t-test, the sample must be tested by normality using liliefors method and homogeneity test by using $F$-test. The results of this study indicate that the use of peer tutoring can provide better learning achievement than the control class that uses the conventional learning model by using directed learning.
\end{abstract}

Keywords: peer tutoring, learning achievement

\begin{abstract}
Abstrak
Pendidikan saat ini mengharuskan proses pembelajaran berpusat pada peserta didik. Hal ini dimaksudkan agar peserta didik turut aktif dalam proses pembelajaran, sehingga ilmu yang terserap lebih maksimal. Pada perguruan tinggi mahasiswa lebih dituntut untuk belajar lebih mandiri. Mahasiswa harus memiliki tanggung jawab pada diri sendiri dan juga kelasnya. Pembelajaran dengan menggunakan Peer Tutoring ini membantu mahasiswa untuk lebih mandiri dan bertanggung jawab pada pembelajaran mereka. Penelitian ini bertujuan untuk membuktikan efektifitas model pembelajaran peer tutoring terhadap prestasi belajar mahasiswa Subyek penelitian ini adalah mahasiswa program studi pendidikan Matematika. Penelitian ini merupakan penelitian eksperimental dengan pendekatan kuantitatif. Analisis data yang digunakan adalah uji statistic dengan t-test. Sebelum dilakukan analisis dengan t-test, sampel diuji normalitasnya dengan menggunakan metode liliefors dan diuji homogenitasnya dengan menggunakan uji $F$. Hasil penelitian ini menunjukkan bahwa penggunaan model pembelajaran peer tutoring mampu menghasilkan prestasi belajar yang lebih baik dari pada kelas kontrol yang menggunakan model pembelajaran konvensional dengan menggunakan model pembelajaran langsung.
\end{abstract}

Kata kunci: Peer Tutoring, Prestasi Belajar.

\section{PENDAHULUAN}

Pemerintah telah menetapkan perubahan besar bagi pendidikan nasional. Pendidikan yang bernuansa tradisional yang selalu berpusat pada pendidik, secara perlahan dituntut untuk berubah. Melalui
Undang-undang sistem pendidikan nasional pemerintah telah memerintah dengan tegas pada lembaga pendidikan agar proses pembelajaran berorientasi pada peserta didik. Peserta didik dituntut untuk aktif dalam proses pembelajaran. 
Pada pendidikan tinggi kesadaran peserta didik dalam hal ini adalah mahasiswa tentu diharapkan berbeda dari para siswa di sekolah menengah. Mahasiswa dituntut untuk lebih mandiri dan bertanggung jawab. Pendidik di perguruan tinggi saat ini masih banyak yang berpusat pada dosen. Kebanyakan proses pembelajaran berlangsung dengan pembelajaran langsung. Dosen menerangkan materi perkuliahan kemudian memberikan tugas kepada mahasiswa. Sehingga bagi mahasiswa dengan kemampuan yang kurang mereka terbiasa dengan menyontek pekerjaan teman mereka. Arief (2017) dalam kompasiana menyebutkan bahwa masih banyak mahasiswa yang menyontek baik dari temannya ataupun dari internet tanpa mencantumkan literature yang jelas. Selain Suyanto dalam Lestari (2008: 146) mengungkapkan bahwa praktek mengajar dosen masih dengan model itu-itu saja, seperti ceramah dan model pembelajarna langsung.

Kebudayaan yang tidak bertanggung jawab seperti menyontek jika tidak ditangani akan semakin memburuk. Maka diperlukan model pembelajaran yang selain bisa memaksimalkan proses pembelajaran tetapi juga menghindari kebiasaan buruk menyontek melalui pembelajaran untuk menjadi lebih bertanggung jawab dan juga prestasi yang lebih baik.

Salah satu model pembelajan yang mengajarkan mahasiswa untuk menjadi lebih bertanggung jawab dan menghasilkan prestasi belajar lebih baik adalah dengan peer tutoring. Melalui pembelajaran peer tutoring mahasiswa diajari untuk bisa bertanggung jawab atas apa yang mereka pelajari. Menurut Hartman dalam Grubbs dan Boes (2009: 23) mengemukakan bahwa peer tutoring mampu meningkatkan rasa kepemimpinan dan tanggung jawab.
Marieswari dan Prema (2016: 2) juga mengatakan "Benefits for tutors such as learning through teaching and becoming more responsibility..." pada peer tutoring peserta didik yang berperan sebagai tutor akan memperoleh manfaat yaitu belajar melalui mengajar dan menjadi lebih bertanggung jawab.

Seiring dengan bertambahnya rasa tanggung jawab mahasiswa makan proses pembelajaran pun akan lebih baik, sehingga prestasi mahasiswa pun akan semakin meningkat. Raheem (2017: 100) menyebutkan dalam penelitiannya bahwa peer tutoring mampu meningkatkan kualitas interaksi peserta didik dan juga meningkatkan kemampuan akademiknya.

Ada beberapa hal yang perlu diperhatikan dalam pembelaran peer tutoting seperti yang dikemukakan oleh Fulk dan King (2001: 49): (1) pemberian penjelasan tentang tujuan dan langkah penggunaan model pembelajaran, (2) pentingnya tanggung jawab bersama dan bekerjasama dari pada berkompetisi, (3) pemilihan materi ajar, (4) melatih peserta didik untuk menjadi tutor dan tutee, (5) memberikan contoh cara pembelajaran dengan peer tutoring, (6) pembagian peserta dalam kelompok atau pasangan, (7) melakukan tutorial dalam kelompok, (8) pemberian umpan balik, dan (9) bergantian peran, dari tutor menjadi tutee dan sebaliknya. Langkah-langkah peer tutoring dalam penelitian ini adalah: (1) dosen menjelaskan tujuan pembelajaran dan langkah penggunaan model pembelajaran, (2) dosen menentukan materi perkuliahan yang akan dibahas, (3) dosen membagi kelas menjadi pasangan-pasangan, dan menentukan tutor dan tutee, (4) setiap pasangan berdiskusi tentang materi yang telah ditetapkan, (5) dosen mengamati dan memfasilitasi apa bila ternyata ada mahasiswa yang merasa kesulitan, (6) 
dosen memberikan umpan balik untuk memantapkan pengetahuan mahasiswa, (7) dosen mengarahkan untuk bergantian peran. (8) dosen memberikan evaluasi di akhir pertemuan.

Tujuan dari penelitian ini adalah untuk mencari tahu apakah model pembelajaran peer tutoring efektif dari pada model pembelajaran langsung terhadap prestasi belajar Matematika pada mahasiswa program studi pendidikan Matematika. Penelitian ini merupakan penelitian eksperimental yang membandingkan anatara kelas kontrol dan kelas eksperimen.

\section{METODE PENELITIAN}

Penelitian ini merupakan penelitian eksperimental. Penelitian ini dilakukan dengan membandingkan nilai prestasi belajar mahasiswa pada kelas kontrol dan kelas eksperimen. Populasi dalam penelitian ini adalah mahasiswa program studi pendidikan Matematika. Sampel dalam penelitian ini adalah mahasiswa program studi pendidikan Matematika pada tingkat 2. Sampel penelitian ini terdiri dari 35 mahasiswa di kelas kontrol, dan 34 mahasiswa untuk kelas eksperimen.

Penelitian ini dilakukan dengan memberikan perlakuan yang berbeda antara kelas kontrol dan kelas eksperimen. Pada kelas kontrol mahasiswa Diberikan pembelajaran pada matakuliah kalkulus peubah banyak dengan pembelajaran konvensional. Pembelajaran konvensional disini menggunakan pembelajaran langsung. Di kelas eksperimen mahasiswa Diberikan pembelajaran pada mata kuliah yang sama namun dengan model pembelajaran yang berbeda, yaitu dengan menggunakan model pembelajaran peer tutoring.

Sebelum Diberikan perlakuan terlebih dahulu diuji keseimbangan antara mahasiswa di kelas kontrol, dan mahasiswa di kelas eksperimen. Nilai yang digunakan untuk uji keseimbangan adalah nilai kuis pada materi sebelumnya. Setelah data dinyataan normal dan homogen Selanjutnya dilakukan uji keseimbangan dengan menggunakan t-tes. Uji keseimbangan dilakukan agar saat Diberikan perlakuan perbedaan yang terjadi adalah memang karena variable bebas yang diteliti, bukan karena kondisi awal yang berbeda.

Setelah kedua kelas diberikan perlakuan dengan dua model pembelajaran yang berbeda Selanjutnya mahasiswa diberikan tes. Tes ini dilakukan untuk memperoleh nilai prestasi belajar mahasiswa. Sama seperti halnya pada uji keseimbangan, hasil tes ini juga akan diuji normalitas dengan menggunakan metode Liliefors dan homogenitas dengan menggunakan uji F. Setelah data dipastikan normal dan homogeny, kemudian dilakukan uji hipotesis dengan menggunakan $t$-test.

\section{HASIL DAN PEMBAHASAN}

Terdapat dua jenis data dalam penelitian ini. Data pertama adalah data kemampuan awal yang didapat dari hasil kuis pada pokok bahasan sebelumnya. Ringkasan data awal tersebut adalah sebagai berikut:

Tabel 1. Ringkasan data awal

\begin{tabular}{ccccc}
\hline Kelas & Jumlah siswa & Rata-rata & Tertinggi & Terendah \\
\hline Kontrol & 35 & 84,63 & 60 & 98 \\
\hline Peer Tutoring & 34 & 88,47 & 68 & 98 \\
\hline
\end{tabular}


Setelah dilakukan uji normalitas dengan menggunakan metode liliefors diperoleh nilai $L_{\text {hitung }}$ untuk kelas kontrol adalah 0,1013 sedangkan nilai $L_{\text {tabel }}$ adalah 0,1498, Sedangkan $L_{\text {hitung }}$ untuk kelas eksperimen adalah 0,1363 dan nilai $L_{\text {tabel }}$ adalah 0,1519 , sehingga dapat disimpulkan bahwa sampel berasal dari populasi yang berdistribusi normal. Selanjutnya dilakukan uji Homogenitas pada kedua data awal tersebut dengan menggunakan uji $F$. Nilai $F_{\text {hitung }}$ yang diperoleh adalah 1,7181 , dan nilai $F_{\text {tabel }}$ adalah 1,7670 . Dengan melihat hasil tersebut dapat disimpukan kedua data tersebut juga homogen. Selanjutnya setelah data dinyatakan normal dan homogen, dilakukan uji keseimbangan dengan t-test dan diperoleh nilai untuk $t_{\text {hitung }}$ adalah 1,6522 dan nilai $t_{\text {tabel }}$ adalah 1,9949 , karena nilai $t_{\text {hitung }}<t_{\text {tabel }}$, maka kedua data dari kelas kontrol dan eksperimen seimbang.

Setelah dilakukan uji keseimbangan dan kedua data dinyatakan seimbang Selanjutnya dilakukan penelitian dengan memberikan perlakuan pada kedua kelas kontrol dan kelas eksperimen. Kelas kontrol diberikan pembelajaran dengan menggunakan pembelajaran konvensional dengan model pembelajaran langsung. Kelas ekperimen diberikan perlakuan dengan pembelajaran peer tutoring. Pembelajaran dilakukan selama 3 bulan selama 8 kali pertemuan. Setelah pembelajaran selesai dilakukan tes di kelas kontrol dan kelas eksperimen. Data dari tes tersebut digunakan untuk menguji hipotesis penelitian. Ringkasan dari data hasil tes adalah sebagai berikut:

Tabel 2. Ringkasan data prestasi

\begin{tabular}{ccccc}
\hline Kelas & Jumlah siswa & Rata-rata & Tertinggi & Terendah \\
\hline Kontrol & 35 & 77,74 & 60 & 86 \\
\hline Peer Tutoring & 34 & 81,20 & 70 & 92 \\
\hline
\end{tabular}

Data prestasi ini kemudian dianalisis dengan menggunakan t-test. Sebelum dilakukan uji t-test terlebih dahulu dilakukan uji normalitas dan homogenitas sebagai uji prasyarat $t$-test.

Uji normalitas dilakukan dengan metode liliefors dengan hasil nilai untuk kelas kontrol $L_{\text {hitung }}=0,0590$ dan $L_{\text {tabel }}=$ 0,1498. Nilai $L$ untuk kelas eksperimen $L_{\text {hitung }}=0,1385$ dan $L_{\text {tabel }}=0,1519$. Nilai $L_{\text {hitung }}$ di kelas kontrol dan kelas eksperimen lebih kecil dari $L_{\text {tabel }}$ sehingga dapat disimpulkan bahwa kedua kelas tersebut berdistribusi normal. Sedangkan setelah dilakukan uji homogenitas dengan menggunakan uji $F$ diperoleh nilai $F_{\text {hitung }}=$ 1,7181 dan $F_{\text {tabel }}=1,7670$ karena nilai $F_{\text {hitung }}<F_{\text {tabel }}$, maka data prestasi juga homogen. Setelah uji prasyarat dilakukan kemudian dilanjutkan dengan uji hipotesis dengan menggunakan t-test. Setelah dilakukan analisis diperoleh nilai $t_{\text {hitung }}=$ 2,3380 , dan $t_{\text {tabel }}=1,9949$. Karena nilai $t_{\text {hitung }}>t_{\text {tabel }}$ maka hipotesis yang menyatakan bahwa penggunaan model pembelajaran peer tutoring lebih efektif dari pada model pembelajaran konvensional dengan menggunakan model pembelajaran langsung.

Hasil penelitian ini juga sesuai dengan hasil penelitian yang dilakukan oleh Safitri (2014: 107), yang menyatakan bahwa peserta didik yang diajar menggunakan model pembelajarn peer tutoring memiliki prestasi lebih baik dari pada peserta didik yang diajar menggunakan model pembelajaran langsung. Selain itu penelitian yang 
dilakukan oleh Comfort dan McMahon (2014: 108) juga menyebutkan bahwa peer tutoring mampu meningkatkan prestasi peserta didik baik yang berperan sebagai tutor atau sebagai tutee. Model pembelajaran peer tutoring lebih efektif dari pada model pembelajaran langsung dikarenakan pada model peer tutoring mahasiswa bukan diajar oleh dosen atau pendidik, melainkan oleh teman mereka sendiri. Mahasiswa diajar atau diberikan tutorial oleh teman sejawat mereka yang mereka sudah terbiasa. Mahasiswa tidak merasa ragu atau takut untuk bertanya karena yang mengajari mereka bukanlah orang dewasa seperti dosen biasanya melainkan teman seumuran mereka.

Dengan mendapatkan tutorial dari teman mereka sendiri mahasiswa akan merasa lebih nyaman, sehingga materi pembelajaran pun bisa terserap lebih optimal. Selain itu bagi mahasiswa yang berperan sebagai tutor juga akan lebih bertanggung jawab, dan mereka akan terdorong untuk selalu bisa. Sehingga dengan memberikan tutorial mereka pun juga belajar.

\section{SIMPULAN}

Setelah dilakukan perlakuan, dan analisis data maka dapat disimpukan bahwa model pembelajaran peer tutoring lebih efektif dari pada model pembelajaran konvensional dengan model pembelajaran langsung. Model pembelajaran peer tutoring memberikan suasana yang lebih nyaman untuk mahasiswa belajar. Peer tutoring juga mengajarkan mahasiswa agar lebih bertanggung jawab.

\section{DAFTAR RUJUKAN}

Arief, R. (2017, Maret 7). Problematika Budaya Menyontek di Indonesia. Retrieved from Kompasiana Beyond
BLogging:

www.kompasiana.com/robbyarief

Comfort, P., \& McMahon, J. J. (2014). The Effect of Peer Tutoring on Academic Achievement. Journal of Appled Reasearch in Higher Education. Vol. 6. Issue: 1, 168-175.

Fulk, B. M., \& King, K. (2001). Classwide Peer Tutoring at Work. Teaching Expectional Children. Vol. 34. No. 2, 49-53.

Grubbs, N., \& Boes, R. S. (2009). An Action Research Study of the Effectiveness of the Peer Tutoring Program at One Suburban Middle School. GSCA Journal. Vol. 16. No.1, 21-31.

Lestari, B. (2008). Peningkatan Kualitas Pembelajran dengan Model Pembelajran Cooperative Learning. Jurnal Ekonomi \& Pendidikan. Vol. 5, No. 2, 145-153.

Marieswari, M., \& Prema, N. (2016). Effectiveness of Peer Tutoring in Learning English among Tutor and Tutees of Class VIII Students in Kancheepuram DT. English Language Teaching. Vol. 9. No. 11, 1-5.

Raheem, Y. A., Yusuf, H. T., \& Odutayo, A. O. (2017). Effect of Peer Tutoring on Students' Academic Performance in Economics in Ilorin South, Nigeria. Journal of Peer Tutoring. Vol. 1o, 95102.

Safitri, D. N. (2014). Eksperimentasi Model Pembelajaran Kooperatif Peer Tutoring dan Mandiri dengan Elearning pada Pokok Bahasan Aljabar 
36 JURNAL PENDIDIKAN EDUTAMA, Vol.5, No.2 Juli 2018

Ditinjau dari Kecerdasan Majemuk.

Jurnal Elektronik Pembelajaran

Matematika. Vol. 2. No. 1, 99-109. 